\title{
Feeding frequency and growth performance of juvenile pink shrimp \\ (Farfantepenaeus paulensis)
}

\author{
[Frequência de oferta alimentar e desempenho zootécnico de juvenis do \\ camarão rosa (Farfantepenaeus paulensis)]

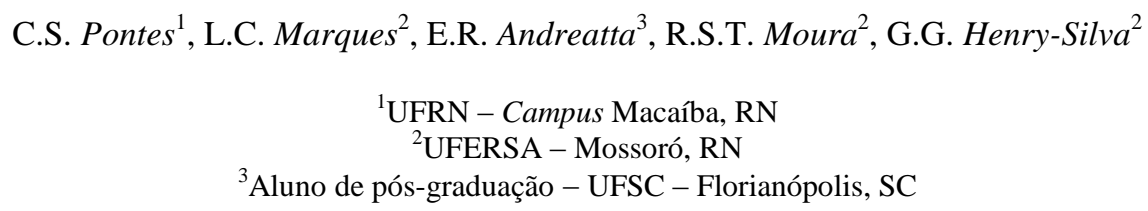

\begin{abstract}
It is generally believed that increasing feeding frequency has immediate benefits, including reduced nutrient leaching and increased shrimp growth. In this context, the aim this work was to evaluate the effect of feeding frequency in growth performance of Farfantepenaeus paulensis. Juveniles of Farfantepenaeus paulensis were grown for 30 days in pen enclosures, at a stocking density of $5 \mathrm{shrimp} / \mathrm{m}$ 2 . The shrimp were fed on feeding trays at a rate of $8 \%$ of their biomass per day, with treatments of one, two, three and four times per day, with four replicates each. The results showed no differences $(5 \%$ probability) in biomass gain of $F$. paulensis when feed was offered two, three or four times per day. However, it was observed that the once a day frequency had a negative influence on weight gain for this species of shrimp. We conclude that the supply of food with $35 \%$ crude protein twice a day is sufficient for the growth of $F$ paulensis. Feeding frequency of three or four times can provide increased spending in the cultivation of juveniles of this species.
\end{abstract}

Keywords: feeding frequency, shrimp culture, aquaculture

\section{RESUMO}

Acredita-se que uma frequência maior de alimentação traz benefícios imediatos, incluindo a redução da lixiviação de nutrientes e o aumento do crescimento do camarão. Nesse contexto, o objetivo do presente trabalho foi avaliar o efeito de diferentes frequências de oferta de alimento sobre o crescimento de Farfantepenaeus paulensis. Juvenis de Farfantepenaeus paulensis foram criados por 30 dias em tanquesrede, na densidade de estocagem de cinco camarões $/ \mathrm{m}^{2}$. Os camarões foram alimentados em comedouros com $8 \%$ da sua biomassa/dia, ofertados em parcelamentos de uma, duas, três e quatro vezes ao dia, com quatro repetições para cada tratamento. Os resultados mostraram que não ocorreram diferenças (5\% de probabilidade) no ganho de biomassa de F. paulensis quando a frequência alimentar foi de duas, três ou quatro vezes ao dia. No entanto, os dados indicam que a frequência alimentar de uma vez ao dia interferiu negativamente no ganho de peso dessa espécie. Conclui-se que o fornecimento de ração com $35 \%$ de proteína bruta duas vezes ao dia é suficiente para o crescimento de F paulensis. $O$ fornecimento de alimento três ou quatro vezes ao dia poderia acarretar maiores gastos no manejo de juvenis dessa espécie.

Palavras-chave: frequência alimentar, carcinicultura, aquicultura

\section{INTRODUCTION}

There is a need for research to provide information for the development of specific methodologies for raising native species that might have a higher commercial value, such as the pink shrimp Farfantepenaeus paulensis. Aquaculture of native shrimp under semiintensive conditions (i.e., pen enclosures or culture pens) may be a sustainable

Recebido em 19 de fevereiro de 2015

Aceito em 3 de julho de 2015

E-mail: cibele.pontes@pq.cnpq.br 
production alternative that improves the welfare of human communities in conservation areas, minimizing the environmental impact of more intensive systems, and avoiding the introduction of potentially invasive species (Valenti and Moraes-Riodades, 2004; Rodríguez-Gallego et al., 2008). However, culture techniques for many native species are not yet established (Lemos et al., 2000).

The feeding strategy used in commercial shrimp farming is determined by its ecological and economic viability and may directly affect the quality of the water and sediments of the ponds (Nunes et al., 1996; Pontes and Arruda, 2008). Also, artificial feed constitutes the most significant fraction of operating costs in aquaculture businesses in general (MartinézCordova et al., 1998; Smith et al., 2002; Venero et al., 2007).

Several factors should be considered in order to develop appropriate feeding management of a shrimp farm. Among these is that shrimp have only rudimentary vision, and detect food via chemosensory structures (Nunes et al., 1996); and that their short digestive tract means that they are quickly satiated (Hill and Wassemberg, 1987). In aquatic medium, the efficiency of a given food depends largely on its being rapidly recognized and accepted (Costero and Meyers, 1993), because its nutrients leach out rapidly after being placed in the water (Cuzon et al., 1982). These considerations suggest that feed should be offered in several daily portions, so that the shrimp can use it more efficiently. Therefore, with the aim of providing information to improve the feeding management in the culture of $F$. paulensis, we evaluated the effects of different frequencies of food offers on the growth performance of juvenile shrimp.

\section{MATERIALS AND METHODS}

The study was carried out in Florianópolis City, Santa Catarina, southern Brazil. Captive-reared juveniles of $F$. paulensis $(4.7 \pm 0.25 \mathrm{~g}, \mathrm{n}=100)$ were obtained from earthen ponds and grown for 30 days at a stocking density of $5 \mathrm{shrimp} / \mathrm{m}^{2}$, in 16 pen enclosures $(1.15 \times 1.15 \times 1.40 \mathrm{~m})$ made of polyester net covered by PVC ( $2 \mathrm{~mm}$ mesh), used as the experimental units. The pen enclosures were arranged randomly in an earthen pond $(0.1 \mathrm{ha})$, the water was renewed by the tidal flow and experimental units did not have artificial aeration.

Temperature and dissolved oxygen were measured at $06 \mathrm{~h} 00$ and $17 \mathrm{~h} 00$, with a mercury thermometer and a polarographic oxygen meter. The $\mathrm{pH}$, total ammonia and salinity were measured at $13 \mathrm{~h} 00$, with colorimetric chemical kits and a refractometer, respectively. The water transparency was measured at $12 \mathrm{~h} 00$ with a Secchi disc. The animals were fed with a pelletized feed containing $35 \%$ crude protein (Tab. 1), so as to provide an amount of feed equal to $8 \%$ of the shrimp biomass/day, divided into similar amounts for each feeding frequency.

Table 1. Proximate composition of ration used for $F$. paulensis feeding

\begin{tabular}{lc}
\hline & Average composition \\
\hline Moisture (max.) & $13.0 \%$ \\
Crude protein (min.) & $35.0 \%$ \\
Ether extract (min.) & $8.0 \%$ \\
Fiber (max.) & $6.0 \%$ \\
Level of ash (max.) & $13.0 \%$ \\
Calcium (max.) & $3.0 \%$ \\
Fósforo (mín.) & $0.7 \%$ \\
Methionine & $500.00 \mathrm{mg}$ \\
Minerals & $0.4 \mathrm{~g}$ \\
Vitamins & $1900 \mathrm{U} . I$. \\
\hline
\end{tabular}

Four different feeding frequencies were used, with 6-h intervals between them, to comprise the following treatments: 1 time/day (21h00), 2 times/day $(09 \mathrm{~h} 00$ and 21h00), 3 times/day (09h00, $15 \mathrm{~h} 00$ and 21h00) and 4 times/day (03h00, 09h00, 15h00 and 21h00), with four replicates each, in a fully randomized experiment.

The feed was offered on feeding trays $(40 \mathrm{~cm}$ diameter) and to evaluate the feed consumption (dry matter/g), the uneaten feed was removed $3 \mathrm{~h}$ after it was offered, and dried in an oven at $60^{\circ} \mathrm{C}$ for $24 \mathrm{~h}$. The feed consumption was estimated from the difference between the amount of feed offered and the amount that was not consumed in each experimental unit. We also calculated the survival $(\%)$, individual weight gain $(\mathrm{g})$ (final individual mean weight, less their initial weights), biomass increase (g) (final weight of all individuals of the experimental unit, less the initial weight) and food conversion (g) (dry weight of feed consumed/biomass increase). 
The adherence of the data residuals to a normal distribution and the homogeneity variances between groups was verified by the ShapiroWilk and Bartlett tests, respectively. A one-way ANOVA analysis was conducted. When significant differences were found, a post-hoc HSD Tukey test was applied. A significance level of 5\% was set to assess the results.

\section{RESULTS}

The water temperature was $24.1 \pm 1.8^{\circ} \mathrm{C}$, the dissolved-oxygen content was $6.4 \pm 0.9 \mathrm{mg} / \mathrm{L}$ and the salinity remained constant at $15 \mathrm{~g} \mathrm{~L}^{-1}$. The mean value for total ammonia was $0.027 \mathrm{mg} \mathrm{L}^{-1}$, with a maximum of $0.036 \mathrm{mg} \mathrm{L}^{-1}$ and a minimum of $0.007 \mathrm{mg} \mathrm{L}^{-1}$. The $\mathrm{pH}$ remained at eight during the entire experimental period. The water

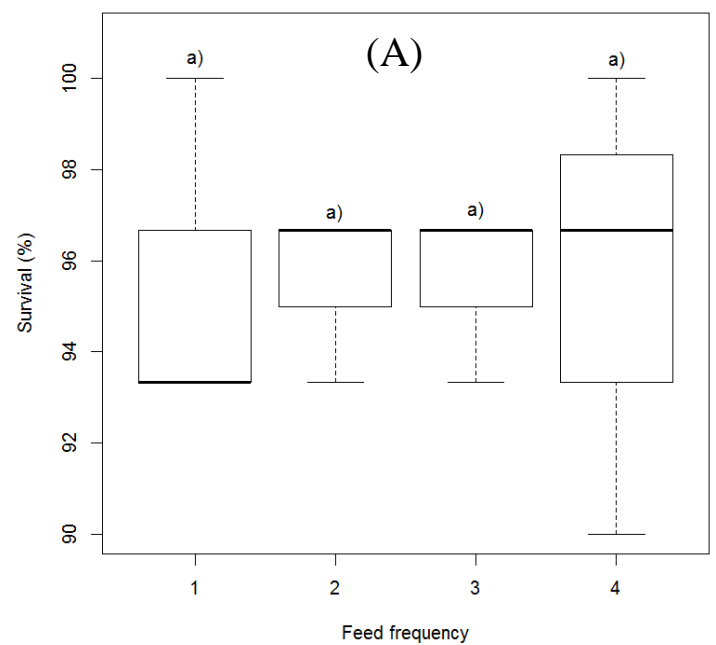

transparency varied from 40 to $50 \mathrm{~cm}$, with a mean of $46 \mathrm{~cm}$.

The overall survival rate of the shrimp was $95.55 \pm 2.00 \%$ (mean \pm standard deviation), with no difference between the treatments $(\mathrm{P}>0.05)$ (Figure 1A). The amount of feed consumed per experimental unit varied with the offering frequency $(\mathrm{P}<0.05)$. The lowest and highest consumption occurred with the treatments 1 time/day $(88.19 \pm 6.08 \mathrm{~g})$ and 4 times/day $(138.33 \pm 7.78 \mathrm{~g})$, respectively. The treatment 1 time/day was similar to 2 times/day $(105.88 \pm 10.79 \mathrm{~g})$, and the latter was equal to 3 times/day $(113.10 \pm 5.16 \mathrm{~g}) \quad(\mathrm{P}>0.05)$; the remaining comparisons were statistically different $(\mathrm{P}<0.05)$ (Figure 1B).

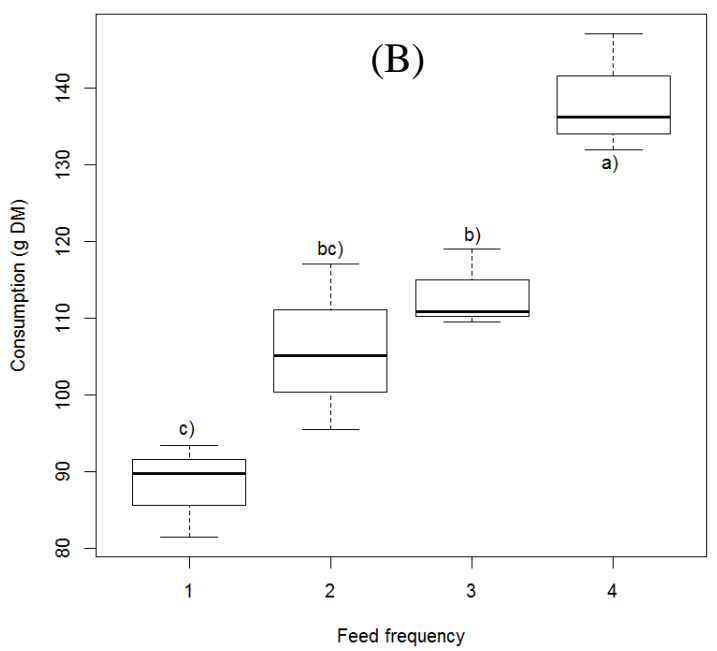

Figure 1. (A) Survival and (B) feed consumption in Farfantepenaeus paulensis according to feed offered at different frequencies. Different superscript letters in the box plots denote significant differences $(\mathrm{P}<0.05) . \mathrm{DM}=$ Dry matter.

Differences in the mean increase of biomass per experimental unit, as a function of the treatments $(\mathrm{P}<0.05)$ were recorded. The frequency of 1 time/day $(17.44 \pm 2.67 \mathrm{~g})$ resulted in a lower increase than those of 2 times/day $(29.43 \pm 0.92)$ and 3 times/day $(29.20 \pm 2.58 \mathrm{~g})$, yet the frequency of 4 times/day $(31.84 \pm 7.77 \mathrm{~g})$ promoted a significantly higher increase in biomass than the other 3 treatments $(\mathrm{P}<0.05)$ (Figure $2 \mathrm{~A})$. The results obtained for individual weight gain followed the same trend, but in this case the mean for the treatment 1 time/day $(0.84 \pm 0.20 \mathrm{~g})$ was lower than that of 2 times/day $(1.28 \pm 0.07 \mathrm{~g})$, 3 times/day $(1.24 \pm 0.11 \mathrm{~g})$ and 4 times/day $(1.33 \pm 0.13 \mathrm{~g}) \quad(\mathrm{P}<0.05)$; these last ones were similar to each other $(P>0.05)$ (Figure $2 \mathrm{~B})$.

The feeding frequency influenced the food conversion rate $(\mathrm{P}<0.05)$. The conversion rate for treatment 1 time/day $(5.10 \pm 0.53)$ was higher and different from the other treatments, witch had no differences among them (Figure 3). 

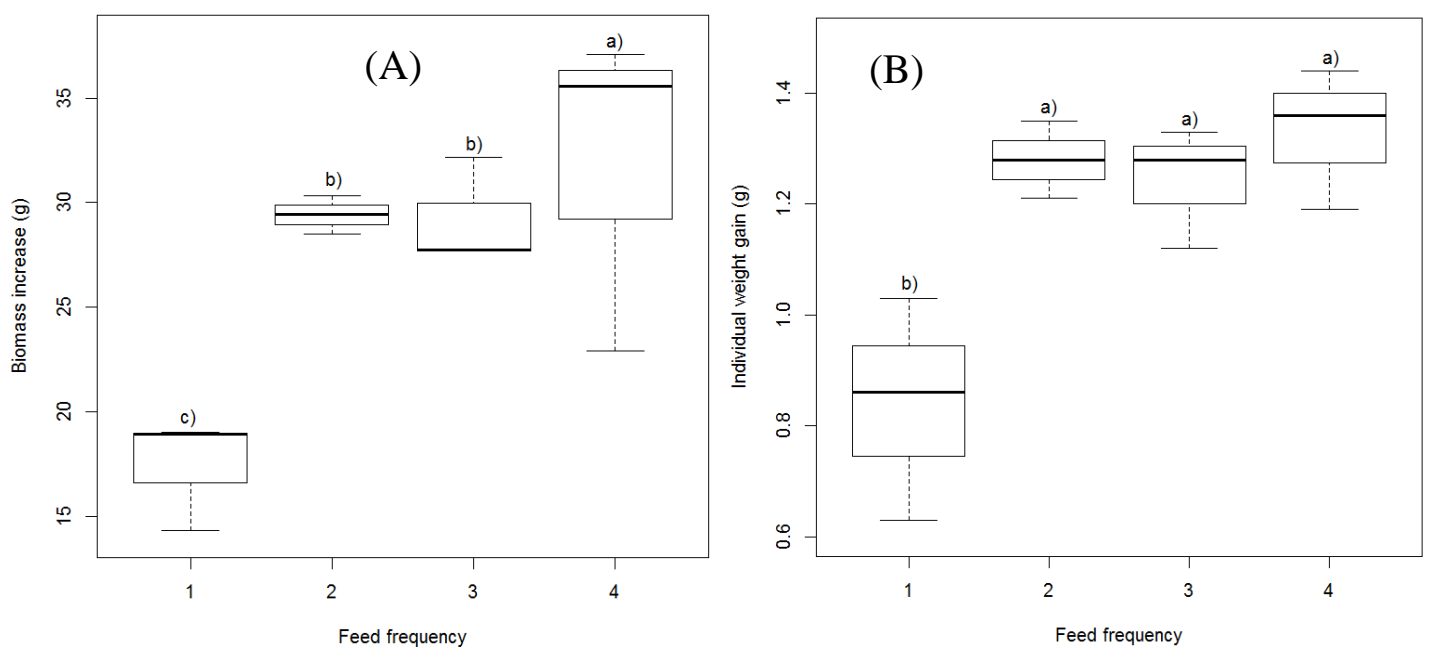

Figure 2. (A) Increase in biomass and (B) individual weight gain in Farfantepenaeus paulensis according to feed offers at different frequencies. Different superscript letters beneath the box plots denote significant differences $(\mathrm{P}<0.05)$.

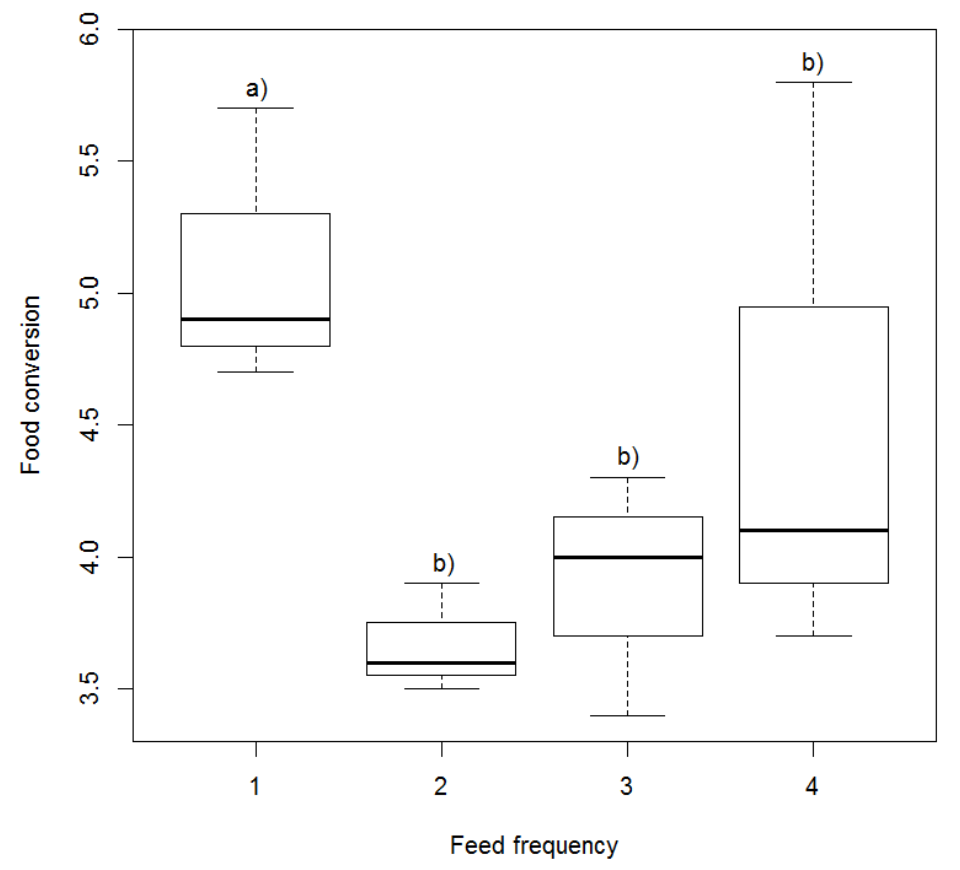

Figure 3. Feed conversion in Farfantepenaeus paulensis according to feed offers at different frequencies $(\mathrm{P}>0.05)$.

\section{DISCUSSION}

For $F$. paulensis grown in pen enclosures, offering feed only once per day is not recommended compared to offering it two, three and four times per day, because, although the results for survival were similar and the food conversion was higher, the consumption of feed was higher and the biomass increase and individual weight gain were smaller. The water quality remained within the appropriate standards for culture and was similar for all the treatments. We can assume that the only source of variation in the experiment was the treatment applied. 
Studies on feeding frequency and its effects on the growth performance of shrimp are conflicting. L. vannamei, Robertson et al. (1993) and Tacon et al. (2002) showed a positive effect on shrimp growth when the feeding frequency was increased. Wyban and Sweeney (1989) found similar results for Fenneropenaeus merguiensis. In agreement with our results for the frequencies of two, three and four times per day, Velasco et al. (1999) did not observe differences in the growth or survival of $L$. vannamei fed three, five, eight, eleven or fifteen times per day. For Penaeus monodon, Smith et al. (2002) evaluated the effect of three, four, five and six feedings per day, and found no differences in growth rate, feed conversion ratio, or survival. Carvalho and Nunes (2006) tested frequencies of two to six times per day for $L$. vannamei, and found no differences in yield and feed conversion ratio.

In contrast to our result for the once per day frequency, Miau and $\mathrm{Tu}$ (1993), testing frequencies of one to four feedings daily, found no differences in the growth of juveniles of Fenneropenaeus penicillatus. Although conversion efficiency has been estimated for different species such as L. vannamei (Velasco et al. 1999), P. monodon (Ye et al., 2009), Litopenaeus stylirostris (Baillet et al. 1997), Fenneropenaeus chinensis (Zhang et al. 2008), no information on this variable has been available for $F$. paulensis.

Pontes and Arruda (2005) observed that L. vannamei accessed the feeding tray and initiated feeding more rapidly in the daylight hours. Also, the digestive tract was fullest one-half hour after the feed was offered, especially in the daylight hours. Pontes et al. (2008), using frequencies of three, four and seven (feed always available) times per day for L. vannamei, showed that offering feed three times a day resulted in the shortest time(s) to access the tray and to ingest the feed, as well as a fuller digestive tract compared with the other frequencies. Animals fed three and four times daily had similar weight gains, and were larger than those fed seven times. The authors argued that the results indicate that a more widely spaced food offering stimulates the shrimp to search for and ingest the feed.
Nunes et al. (1996) stated that juveniles of Farfantepenaeus subtilis feed during both day and night, and that ingestion of food (artificial and natural) always increases after the feed is distributed in the pond, most intensely in the first $10 \mathrm{~min}$ after the food is added. Specifically for $F$. paulensis, Soares et al. (2005) found that the greatest reduction in stomach fullness occurred three hours after food was removed. Authors suggested that it might be possible to optimize feed utilization and to reduce the accumulation of uneaten feed by distributing the daily ration in multiple feedings at 4-h intervals. The absence of a correlation between shrimp size and gastric emptying allows the same feeding frequency to be used over the range of sizes tested $(1.36 \pm 0.43$ to $7.23 \pm 0.5$ ).

\section{CONCLUSION}

The results showed no significant differences in biomass gain of $F$. paulensis when feed was offered two or three times per day, revealing, however, a reduced gain for the frequency of 1 time per day. Yet it is observed that the once a day frequency had negative influence on weight gain for this species of shrimp. Thus, we conclude that for $F$. paulensis fed diets containing $35 \%$ crude protein, the supply of food twice a day is sufficient for its growth. The feed frequency of three or four times per day could lead to higher expenses in the handling of juveniles of this species.

\section{ACKNOWLEDGMENTS}

We thank the National Research and Development Council (CNPq), CUNHAMAR Shrimp Farm, Dr. Janet W. Reid for the English translation and the staff of the Shrimp Laboratory of the Department of Aquaculture, Federal University of Santa Catarina.

\section{REFERENCES}

BAILlET, C.; CUZON, G.; COUSIN, M.; KERLEGUER, C. Effect of dietary protein levels on growth of Penaeus stylirostris juveniles. Aquac. Nutr., v.3, p.49-53, 1997.

CARVALHO, E.A.; NUNES, A.J.P. Effects of feeding frequency on feed leaching loss and grow-out patterns of the white shrimp Litopenaeus vannamei fed under a diurnal feeding regime in pond enclosures. Aquaculture, v.252, p.494-502, 2006. 
COSTERO M.T.; MEYERS, S. Evaluation of chemoreception by Penaeus vannamei under experimental conditions. Prog. Fish Cult., v.55, p.157162, 1993.

CUZON, G.; HEW, M.; COGNIE, D.; SOLETCHNIK, P. Time lag effect of feeding on growth of juvenile shrimp Penaeus japonicus BATE. Aquaculture, v.29, p.33-44, 1982.

HILL, B.J.; WASSENBERG, T.J. Feeding behaviour of adult tiger prawns, Penaeus esculentus, under laboratory conditions. Aust. J. Mar. Freshw. Res., v.38, p.83-189, 1987.

LEMOS D.; EZQUERRA, J.M.; GARCIACARREÑO, F.L. Protein digestion in penaeid shrimp: digestive proteinases, proteinase inhibitors and feed digestibility. Aquaculture, v.186, p.89-105, 2000.

MARTINÉZ-CORDOVA, L.R.; PORCHASCORNEJO, A.; VILLARREAL-COLEMNARES, $\mathrm{H}$. et al. Evaluation of three feeding strategies on the culture of white shrimp Penaeus vannamei Boone 1931 in low water exchange ponds. Aquacult.l Eng., v.17, p.21-28, 1998.

MIAU, S.; TU, S. Modeling the effect of daily ration and feeding frequency on growth of redtail shrimp Penaeus penicillatus (Alock) at controlled temperatures. Ecol. Model., v.70, p.305-321, 1993.

NUNES, A.J.P.; GODDARD, S.; GESTEIRA, T.C.V. Feeding activity patterns of southern brown shrimp Penaeus subtilis under semi-intensive culture in NE Brazil. Aquaculture, v.144, p.371-386, 1996.

PONTES C.S.; ARRUDA M.F. Acesso ao alimento artificial e enchimento do trato digestivo de juvenis do camarão marinho Litopenaeus vannamei (Boone) (Crustacea, Decapoda, Penaeidae) durante as fases clara e escura do período de 24 horas. Braz. J. Zool., v.22, p.1039-1043, 2005.

PONTES, C.S.; LIMA, P.P.; ARRUDA, M.F. Feeding responses of juvenile shrimp Litopenaeus vannamei (Boone) fed at different frequencies under laboratory conditions. Aquacult. Res., v.39, p.1416-1422, 2008.

ROBERTSON L.; LAWRENCE, A.L.; CASTILLE, F.L. Effect of feeding frequency and feeding time on growth of Penaeus vannamei (Boone). Aquacult. Fish. Manag., v.24, p.01-06, 1993.
RODRÍGUEZ-GALLEGO L.; MEERHOFF, E.; POERSCH, L. et al. Establishing limits to aquaculture in a protected coastal lagoon: Impact of Farfantepenaeus paulensis pens on water quality, sediment and benthic biota. Aquaculture, v.277, p.3038, 2008.

SMITH, D.M.; BURFORD, M.A.; TABRETT, S.J. et $a l$. The effect of feeding frequency on water quality and growth of the black tiger shrimp (Penaeus monodon). Aquaculture, v.207, p.125-136, 2002.

SOARES, R.; WASIELESKY, W.; PEIXOTO, S.; D'INCAO, F. Food consumption and gastric emptying of Farfantepenaeus paulensis. Aquaculture, v.250, p.283-290, 2005.

TACON, A.J.G.; CODY, J.J.; CONQUEST, L.D. et al. Effect of culture system on the nutrition and growth performance of Pacific white shrimp Litopenaeus vannamei (Boone) fed different diets. Aquacult. Nutr., v.8, p.121-137, 2002.

VALENTI, W.C.; MORAES-RIODADES, P.M.C. Freshwater prawn farming in Brazil. Global Aquacult. $A d v$., v.7, p.52-53, 2004.

VELASCO, M.; LAWRENCE, A.L.; CASTILLE, F.L. Effect of variations in daily feeding frequency and ration size on growth of shrimp Litopenaeus vannamei (Boone), in zero-water exchange culture tanks. Aquaculture, v.179, p.141-148, 1999.

VENERO, J.A.; DAVIS, D.A.; ROUSE, D.B. Variable feed allowance with constant protein input for the pacific white shrimp Litopenaeus vannamei reared under semi-intensive conditions in tanks and ponds. Aquaculture, v.269, p.490-503, 2007.

WYBAN, J.A.; SWEENEY, J.N. Intensive shrimp growout trials in a round pond. Aquaculture, v.76, p.215-225, 1989.

YE, L.; JIANG, S.; ZHU, X. et al. Effects of salinity on growth and energy budget of juvenile Penaeus monodon. Aquaculture, v.290, p.140-144, 2009.

ZHANG C., F. LI, K. YU; XIANG, J. 2008. Comparative growth performances of diploid and triploid Chinese shrimp Fenneropenaeus chinensis (Osbeck, 1765) under different salinities. Aquacult. Res., v.39, p.962-969, 2008. 